\title{
应用我国再入返回飞行器服务舱探测到较强月球 电离层信号
}

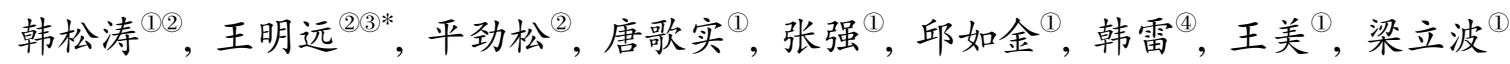

(1) 北京航天飞行控制中心航天飞行动力学技术重点实验室, 北京 100094;

(2) 中国科学院国家天文台月球与深空探测研究重点实验室, 北京 100012;

(3) 中国科学院行星科学重点实验室, 上海天文台, 上海 200030;

(4) 西安卫星测控中心宇航动力学国家重点实验室, 西安 710043

* 联系人, E-mail: wangmy@bao.ac.cn

2016-03-23 收稿, 2016-07-06 修回, 2016-07-06 接受, 2016-10-12 网络版发表

国家自然科学基金(41590851，61401014)、国家重点基础研究发展计划(2015CB857101)和国家重点实验室基金(9140C990207140C99002) 资助

摘要 月球电离层的存在是一个具有争议性的问题。迄今为止, 前苏联、美国、欧洲和日本先后采用掩星及就 位观测手段对月球电离层进行了探测, 探测结果存在一定差异. 为探测及研究月球电离层, 利用我国月球探测工 程再入返回飞行器服务舱在地面测量站开展了自主的 S/X相千双频掩星观测. 本文采用本地相关处理方法提取各 频点连续精确的相位信息, 初步获得了月球电离层电子柱浓度的探测结果, 证实了月球电离层的存在, 同时提出 了新问题：为什么存在如此强的月球电离层?

关键词月球电离层, 再入返回飞行器, 掩星, 本地相关, 电子柱浓度

到目前为止, 前苏联、美国、欧洲、日本先后在 其月球探测任务中开展过有关月球电离层的探测试 验研究 ${ }^{[1 ~ 3]}$. 二十世纪六七十年代, 美国Pioneer 7 掩 星观测得到月球电离层电子密度约为 $4 \times 10^{7} \mathrm{el} / \mathrm{m}^{3}$, 阿 波罗 14 号搭载的月球环境带电粒子探测仪测得的地 表几百米左右的电子密度为 $10^{4} \mathrm{el} / \mathrm{cm}^{3[4]}$; 前苏联Luna 19/22掩星观测得到的一系列电子密度廓线最大值在 $500 \sim 2300 \mathrm{el} / \mathrm{cm}^{3}$ 范围内 ${ }^{[5,6]}$. 21 世纪前 10 年, 欧洲太空 局的SMART-1也进行了月球电离层掩星观测, 至今 还没有具体结果发表; 日本SELENE探测器的月球电 离层掩星观测使用获得的全部数据在适当的太阳高 度角条件下给出了一个有效电子密度廓线, 其最大 电子密度约为 $300 \mathrm{el} / \mathrm{cm}^{3[7,8]}$. 多次观测结果的前后不 一致性、SELENE测量噪声与观测结果相当甚至更大,
以及对其探测方法的可靠性质疑等, 导致月球稀薄 的电离层在 40 多年以来一直是一个具有争议的课题, 人们对其广泛存在性和成因仍然有很多疑问.

无线电掩星观测是行星无线电技术的一种应用 形式, 它根据目标行星的探测器到地球测站的载波 无线电信号产生的相位变化, 开展行星大气和电离 层结构等科学问题研究 ${ }^{[9,10]}$. 经仔细分析确认, 发现 我国2014年底发射的月球探测工程再人返回飞行器 服务舱(简称服务舱)在满足掩星几何构型要求以及 一定的飞行姿态条件下，可以提供星-地链路的月球 无线电掩星观测机会. 经过申请和协调的技术测试 验证, 利用这个工程验证任务的服务舱和地面测站 独立地开展了月球中纬度地区 $\mathrm{S} / \mathrm{X}$ 双频的电离层掩星 无线电科学观测. 该项探测工作使用本地相关算法

引用格式: 韩松涛, 王明远, 平劲松, 等. 应用我国再人返回飞行器服务舱探测到较强月球电离层信号. 科学通报, 2016, 61: 3476-3481 Han S T, Wang M Y, Ping J S, et al. Exploring strong lunar ionosphere successfully with the service module of Chinese circumlunar return and reentry spacecraft (in Chinese). Chin Sci Bull, 2016, 61: 3476-3481, doi: 10.1360/N972016-00386 
优化掩星数据处理, 提高了对月球电离层电子密度 测量的灵敏度和分辨能力, 借助探测器绕月轨道的 大倾角特性对月球中纬度边缘地区上空进行了首次 自主的月球电离层掩星观测, 探测到了较强的电离 层, 进一步证实了月球电离层的存在.

\section{1 再入返回飞行器服务舱}

我国探月三期再人返回飞行器于 2014 年 10 月 24 日发射升空, 11 月 1 日返回器顺利着陆后, 服务舱先 后完成了环地-月L2点探测等拓展试验, 目前正在开 展月球重力场探测等拓展科学试验 (http://digitalpaper. stdaily.com/http_www.kjrb.com/kjrb/html/2015-03/09/ content_294978.htm?div=-1). 通过对星载微波测控通 信系统的设计与状态分析, 确认其搭载的 X波段 VLBI信标与 S波段对地数传模式之一的频率源皆由 星上同一晶体振荡器提供频率参考, 该晶体振荡器 的短期稳定度为 $n \times 10^{-9}$ 量级, 相对于 SELENE任务 VLBI小卫星搭载的晶体振荡器的 $n \times 10^{-7}$ 量级短期稳 定度 ${ }^{[11]}$ 高出 2 个量级, 是开展双频掩星观测的稳定的 信号源. 服务舱搭载的微波设备在某些个别的特殊 飞行弧段, 在不改变飞行器姿态的情况下, 其X波段 和 $\mathrm{S}$ 波段的天线信号可同时发向地球, 提供了双频掩 星观测的空间几何构型条件.

结合服务舱运行轨道以及地面跟踪测站的信息, 协调了对服务舱的掩星技术状态验证试验, 之后申 请了佳木斯深空站、喀什深空站的观测时间, 开展 了服务舱绕月飞行的掩星观测, 使用测站配置的 VSR采集系统实现试验数据的采集记录(如图1), 并 通过事后处理分析初步获取了月球表面至其上 $50 \mathrm{~km}$ 高度以内的电离层信息.

\section{2 基本原理及数据处理方法}

\section{1 双频掩星观测}

单颗卫星的对月地基掩星观测模式如图 2所示, 卫星发出的 $\mathrm{S} / \mathrm{X}$ 双频信号, 经过月球电离层、地-月 空间等离子体介质、地球的电离层和大气层, 被地 面测站的设备接收. 地面站配置了氢原子钟作为开 环观测模式的频率参考源, VSR设备在70 MHz低中 频端采集数据, $\mathrm{ADC}$ 采用 8 位量化, 记录带宽是 1 或 2 MHz. 一次观测获得的数据量约 4 GB. 事后证明8位 量化满足了观测需求.

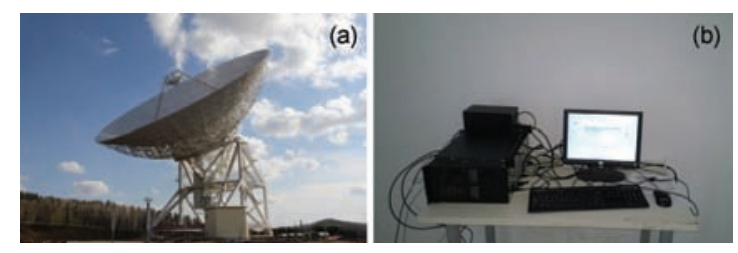

图 1 (网络版彩色)地面跟踪测站(a)及数据采集设备(b)

Figure 1 (Color online) Ground tracking station (a) and radio science receiver (b)

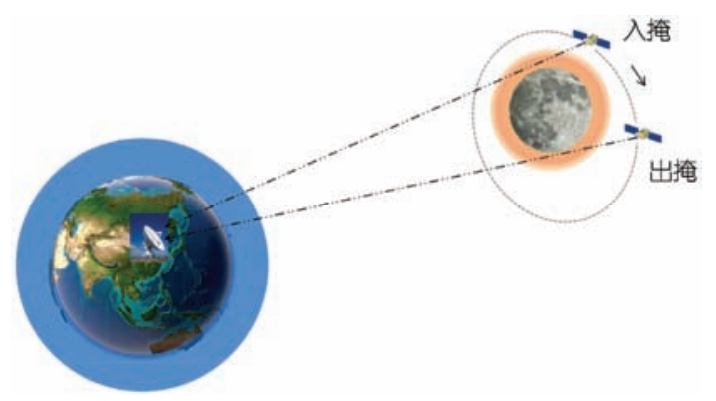

图 2 (网络版彩色)星地掩星示意图

Figure 2 (Color online) Illustration of earth-based lunar occultation

绕月服务舱微波信号到达地面站之前会受到月 球电离层、地-月空间等离子体、地球电离层、地球 大气层的影响. 在掩星时段(数分钟左右), 地球中性 大气层和地球测站的接收设备产生的载波相位变化 量与工作频率成线性关系 ${ }^{[7]}$, 经过 $\mathrm{S} / \mathrm{X}$ 信号相位差分 后，相同的误差源被消除; 而月球电离层、地-月空 间等离子体介质和地球电离层传播路径引起的卫星 信号相位变化量与卫星信号的频率的平方成反比.

假设航天器下行的相干频率 $f_{1}$ 和 $f_{2}$ 的载波相位 分别为 $\Phi_{1}$ 和 $\Phi_{2}$, 则掩星期间视向方向的电子柱浓度 可表征为 ${ }^{[12]}$

$$
E=\frac{1}{2 \pi} \frac{c}{40.3} \frac{f_{1}^{2} f_{2}^{2}}{f_{2}^{2}-f_{1}^{2}} \frac{1}{f_{1}}\left(\Phi_{1}-\frac{f_{1}}{f_{2}} \Phi_{2}\right) .
$$

\section{2 数据处理方法}

（i ）载波相位提取. 高精度提取载波相位是获 得月球电离层信息的基础，本文应用研究团队研发 的本地相关处理方法提取频率及载波相位信息 ${ }^{[13]}$, 用于抑制星载晶体振荡器的稳定特性对其他传统的 时域或频域提取算法带来的噪声干扰，大幅提高这 类信号处理的效率. 本地相关处理方法的核心是在 数据接收终端重构接收信号的精确模型, 利用相关 计算实现观测量的提取. 
(ii) 地球电离层影响消除. 地球大气层、电离 层等干扰的抑制是进行高精度电离层电子柱浓度提 取的关键. 在地-月之间观测链路的视线方向上, 地 球电离层、地-月空间等离子体和稀薄的月球电离层 混合在一起. 由于月球掩星事件时长很短 (小于 $100 \mathrm{~s}$ ), 在这样短时间内, 除非在地球磁暴或者其他空间天 气事件导致地球电离层短时爆发, 地-月空间等离子 体也发生巨大变化, 否则两者的变化是可以预测的. 据我们确认, 在本次观测时间段内, 台站附近电离层 没有此类因素导致的巨大变化.

本文采用研究者在这类观测中常用的趋势外推 算法 ${ }^{[14,15]}$, 扣除地球电离层和地-月空间等离子体的 干扰误差. 趋势外推算法的基本思想是选取只包含 地球电离层和地-月空间等离子体信息(如门限高度 选取 $60 \mathrm{~km}$ ) 的观测时段, 由于这部分电子柱浓度在 数十秒到百秒以内线性变化占主导, 选取合适的拟 合阶数对其拟合, 然后把拟合趋势外推到距离月表 0 60 km高度区间, 利用观测结果与外推的趋势项差 分, 消除地-月空间等离子体和地球电离层的干扰影 响, 从而得到月表附近的月球电离层电子柱浓度.

\section{3 试观测试验情况}

在星地掩星的轨道约束分析基础上, 选择佳木 斯深空站对再人返回飞行器服务舱的出掩弧段进行 跟踪测量, 采用提前注人指令工作模式, 避免信号开 启滞后于卫星出掩弧段. 应用上文论述的本地相关 处理算法提取 $\mathrm{S} / \mathrm{X}$ 双频信号的载波相位, 在 $1 \mathrm{~s}$ 积分时 间内，相位估计精度分别为 0.024 和 $0.070 \mathrm{rad}$.

结合 $\mathrm{S} / \mathrm{X}$ 相参信号的相干比, 将 $\mathrm{S}$ 波段相位信息 折算到X波段频点上, 对两路相位进行差分, 得到差 分相位如图3(c)蓝线所示, 红色标注线是利用80 200 $\mathrm{km}$ 的差分相位进行线性拟合后，外推小于 $80 \mathrm{~km}$ 弧段 对应的地球电离层(包含地面接收系统常量影响、处 理相位整周模糊度等)干扰引人的相位.

将初始得到的差分相位扣除干扰趋势相位, 利 用公式(1)提取月表附近的电子柱浓度. 图4中给出了 分别记录于 2015年10月27日(红色)和2016年1月24日 (蓝色)的两个掩星事件中的电子柱浓度随高度的变 化趋势, 在50 $\mathrm{km}$ 以下其随高度增加而递减, 最大值 分别为 $0.4 \times 10^{16}$ 和 $0.5 \times 10^{16} \mathrm{el} / \mathrm{m}^{2}$, 平均值在 $0.2 \times 10^{16} \sim$ $0.3 \times 10^{16} \mathrm{el} / \mathrm{m}^{2}$.

\section{4 结果和讨论}

观测试验的分析结果表明基于月球探测工程再 人返回飞行器服务舱掩星观测初步成功获取了月表以 上至 $50 \mathrm{~km}$ 左右的电子柱浓度信息, 最大处为 $0.4 \times$ $10^{16} \sim 0.5 \times 10^{16} \mathrm{el} / \mathrm{m}^{2}$, 通过对原始相位观测量进行误差 估算并进行误差传递计算后, 获得电子柱浓度误差 $(3 \sigma)$ 为 $\pm 0.012 \times 10^{16} \mathrm{el} / \mathrm{m}^{2}$. 这个观测结果与美国阿波罗 14 号搭载的月球环境带电粒子探测仪观测量级一致 ${ }^{[4]}$, 约为前苏联Luna 19/22观测结果中最大值的两倍 ${ }^{[5,6]}$, 高于SELENE任务探测结果 1 2 个量级 ${ }^{[8]}$. 本次观测结 果进一步证实了月球电离层的存在, 在太阳活动谷年 观测得到的月球电离层比以往都强, 是一个新的科学 问题. 对比本次试验和其他观测的几何条件发现，太 阳辐射及其高度角对月球电离层有显著影响, 但不是 主要或唯一原因, 不排除月球外逸层的贡献被显著低 估的可能, 将在获得更多观测数据后开展有关月球电 离层产生机制方面的分析与研究.

为对比历次月球无线电掩星试验, 本文给出了目
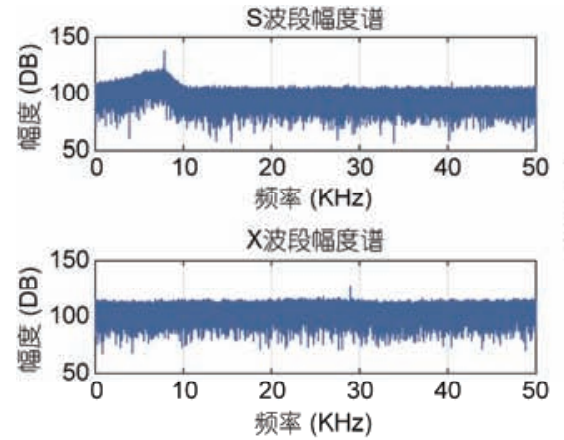

(a)

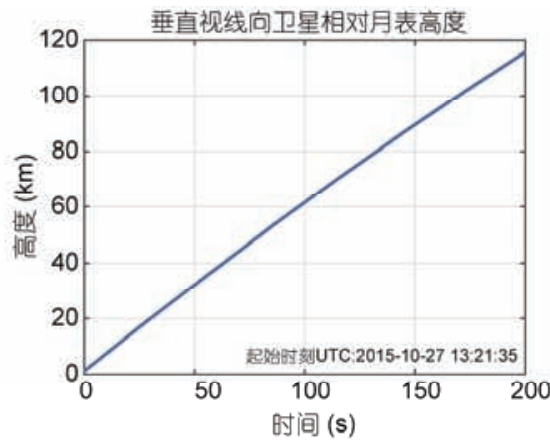

(b)

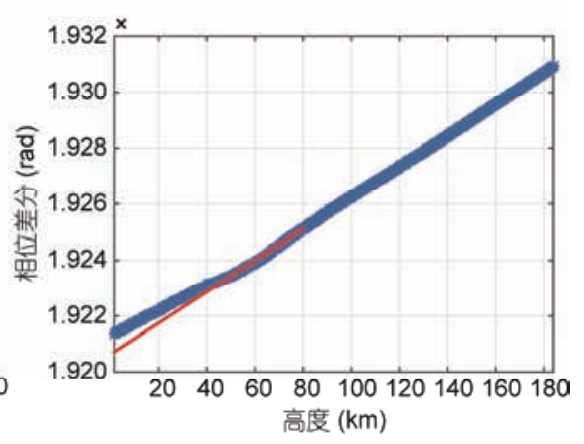

(c)

图 3 (a) 一次掩星事件的信号频谱图; (b) 掩星弧段卫星高度; (c) 差分载波相位

Figure 3 (a) In an occultation event, the amplitude spectrum of the S/X signal; (b) the altitude of the satellite; (c) the differential phase of signal 


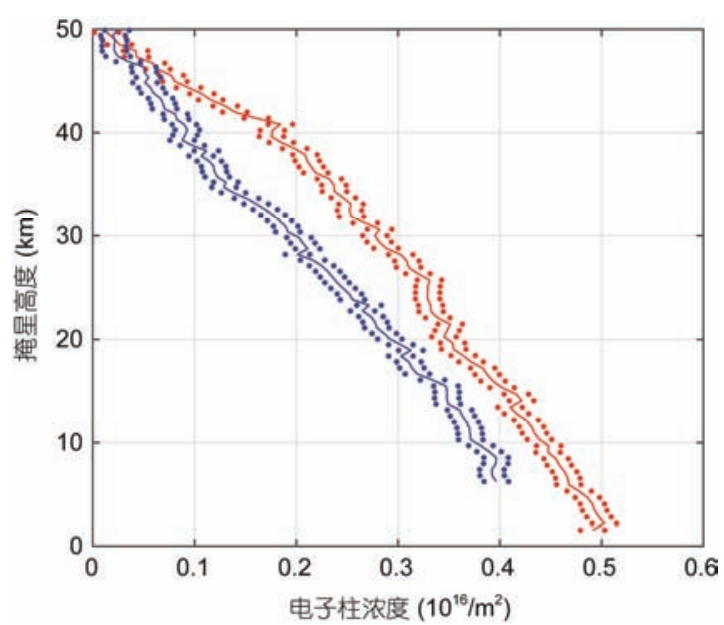

图 4 月球电离层电子柱浓度随高度的变化

Figure 4 The electron column concentration of lunar ionosphere changing with height

前成功获取的探测结果的相关试验关键参数. 由表 1 可见，本次掩星试验具有同类试验中最高的星上晶 振稳定度和最高的地面采样率; 由于SELENE任务用
于月球电离层探测的VLBI子卫星采用约 $0.18 \mathrm{~Hz}$ 的稳 定自旋控制姿态，导致 $0.18 \mathrm{~Hz}$ 基频和高倍频谐波项、 缓慢进动的低频周期项以及长期项带给卫星发出的 电磁波几十度的偏差, 特别是低频项和长期项无法 扣除, 直接影响到其观测结果 ${ }^{[15]}$, 使对其结果的准 确性和可靠性仍存在质疑. 再人返回飞行器服务舱 采用了三轴稳定的卫星, 不存在此类问题. 本次试验 中地面站配备了氢原子钟作为接收机的频率参考, 大幅提高观测精度.

本次试验借助探测器轨道大倾角特性对中纬度 地区边缘上空进行月球电离层的首次自主观测, 探 测到存在较大的电离层, 进一步证实了月球电离层 的存在. 后续, 我们将继续克服技术工程方面的困 难, 在探测器完成2016年度的月球重力场探测拓展 科学试验之后, 力争把掩星观测列人正式的拓展科 学试验, 协调并开展更多的观测, 以期获得多历元观 测资料, 进一步开展月球电离层及其成因、分布特性 方面的工作.

\section{表 1 历次有观测结果的月球掩星试验关键参数表}

Table 1 The key parameters in previous successful lunar occultation experiments

\begin{tabular}{llll}
\hline 航天器 & 星上晶振稳定度 & 采样率 & 卫星状态 \\
\hline Luna $19 / 22$ & $10^{-7}(\sim 600 \mathrm{~s})$ & $0.2 \mathrm{sps}$ & 三轴稳定 \\
SELENE & 短稳 $10^{-7}$ & $40 \mathrm{sps}$ & 自旋, 频率为 $0.18 \mathrm{~Hz}$ \\
再人返回飞行器服务舱 & 短稳 $10^{-9}$ & $100 \mathrm{sps}$ & 三轴稳定 \\
\hline
\end{tabular}

\section{参考文献}

1 Goto Y, Fujimoto T, Kasahara Y, et al. Lunar ionosphere exploration method using auroral kilometric radiation. Earth Planets Space, 2011, 63: 47-56

2 Wei H, Murray L B. A theoretical lunar ionosphere. Icarus, 1962, 1: 346-356

3 Daily W D, Barker W A, Clark M, et al. Ionosphere and atmosphere of the moon in the geomagnetic tail. J Geophys Res, 1977, 82: $5441-5451$

4 Pluchino S, Schillirò F, Salerno E, et al. Radio occultation measurements of the lunar ionosphere. Mem S Astron It Suppl, 2008, 12: $53-59$

5 Stubbs T J, Glenar D A, Farrell W M, et al. On the role of dust in the lunar ionosphere. Planet Space Sci, 2011, 59: 1659-1664

6 Vyshlov A S. Preliminary results of circumlunar plasma research by the Luna 22 spacecraft. In: Proceedings of the Open Meetings of Working Groups on Physical Sciences. Berlin: Akademie-Verlag GmbH, 1976. 945-949

7 Imamura T, Iwata T, Yamamoto Z I, et al. Studying the lunar ionosphere with SELENE radio science experiment. Space Sci Rev, 2010, 154: $305-316$

8 Imamura T, Nabatov A, Mochizuki N, et al. Radio occultation measurement of the electron density near the lunar surface using a subsatellite on the SELENE mission. J Geophys Res Space Phys, 2012, 117: 1-8

9 Ping J S, Huang Y D, Wang M Y, et al. The possibility of detection of Mars ionosphere by radio occultation (in Chinese). Deep Space 
Explor, 2007, 2: 18-25 [平劲松, 黄逸丹, 王明远, 等. 无线电掩星技术观测火星夜间电离层的可行性. 深空探测研究, 2007, 2: 18-25]

10 Wu M J, Guo P, Hu X G, et al. Research on error analysis of ionosphere detection by radio occultation (in Chinese). Annu Publ Shanghai Astron Observat, Chin Acad Sci, 2014, 1: 99-111 [仵梦婕, 郭鹏, 胡小工, 等. 无线电掩星技术探测电离层的误差分析研究. 中国科 学院上海天文台年刊, 2014, 1: 99-111]

11 Imamura T, Oyama K, Iwata T, et al. The possibility of studying the lunar ionosphere with the SELENE radio science experiment. Earth Planets Space, 2008, 60: 387-390

12 Wolt M K, Aminaei A, Zarka P, et al. Radio astronomy with the European lunar lander: Opening up the last unexplored frequency regime. Planet Space Sci, 2012, 74: 167-178

13 Han S T, Tang G S, Chen L, et al. Algorithm and demonstration of DOR tracking model reconstruction (in Chinese). Spacecr Eng, 2014, 23: 91-94 [韩松涛, 唐歌实, 陈略, 等. DOR 测量自适应模型重构算法与实验验证. 航天器工程, 2014, 23: 91-94]

14 Ando H, Imamura T, Nabatov A, et al. Dual-spacecraft radio occultation measurement of the electron density near the lunar surface by the SELENE mission. J Geophys Res Atmos, 2012, 117: 516-525

15 Wang Z. Study of lunar ionosphere detection (in Chinese). Dissertation for Doctoral Degree. Beijing: University of Chinese Academy Sciences, 2015 [王震. 月球电离层探测研究. 博士学位论文. 北京: 中国科学院大学, 2015] 


\title{
Exploring strong lunar ionosphere successfully with the service module of Chinese circumlunar return and reentry spacecraft
}

\author{
HAN SongTao ${ }^{1,2}$, WANG MingYuan ${ }^{2,3}$, PING JinSong ${ }^{2}$, TANG GeShi ${ }^{1}$, ZHANG Qiang ${ }^{1}$, \\ QIU RuJin ${ }^{1}$, HAN Lei ${ }^{4}$, WANG Mei ${ }^{1} \&$ LIANG LiBo $^{1}$ \\ ${ }^{1}$ Science and Technology on Aerospace Flight Dynamics Laboratory, Beijing Aerospace Control Center, Beijing 100094, China, \\ ${ }^{2}$ Key Laboratory of Lunar and Deep Space Exploration Research, National Astronomical Observatories, Chinese Academy of Sciences, Beijing \\ 100012, China; \\ ${ }^{3}$ Key Laboratory of Planetary Sciences, Shanghai Astronomical Observatory, Chinese Academy of Sciences, Shanghai 200030, China; \\ ${ }^{4}$ State Key Laboratory of Astronautic Dynamics, China Xi'an Satellite Control Center, Xi'an 710043, China
}

The existence of lunar ionosphere has been under debate for a long time. In Apollo 14 mission, the electron density detected by the charged particle lunar environment experiment (CPLEE) was $10^{4} \mathrm{el} / \mathrm{cm}^{3}$ at several hundred meters high during lunar day time. In Luna-19/22 mission, the electron density profiles were detect and the peak densities were about $10^{3} \mathrm{el} / \mathrm{cm}^{3}$. In the last decade, European mission SMART-1 and Japanese mission SELENE also performed radio occultation experiment for lunar ionosphere. The results of these missions don't well-matched. In order to explore the lunar ionosphere, a very low frequency radio astronomical payload has been suggested to be sent to the surface of lunar far-side by the Chinese Chang'E-4 lunar lander mission in 2019. The payload will record the Type II solar burst, which may cover the frequency of electro-magnetic wave as low as several dozen kilo-Herz. The possible lunar ionosphere above the payload with certain electron density may truncate or block the solar burst signal as corresponding plasma frequency. To estimate the possible truncate frequencies for these observations by the new kind of payload, and to determine the lunar ionospheric distribution, an lunar radio occultation experiment with the service module of Chinese circumlunar return and reentry spacecraft has been performing. The circumlunar return and reentry spacecraft is a Chinese precursor mission for the Chinese lunar sample return mission. It was launched on 23 October 2014. After the return and reentry experiments, the service module went back into a Lunar Orbit on 11 January 2015 to image the target landing zone for the Chinese lunar sample return mission which has not yet been disclosed. During this period, the radio occultation experiments have been performed to detect the lunar ionosphere. The service module provides a stable and reliable frequency source, whose short-term stability is $n \times 10^{-9}$, for both X-band and S-band signal. The signals transmitted from the spacecraft in $\mathrm{S}$ and $\mathrm{X}$ band passed through lunar ionosphere, interplanetary plasma, Earth ionosphere and atmosphere, finally received by the ground tracking stations. According to the coherent ratio of the $\mathrm{S} / \mathrm{X}$ signal, we convert the phase information of S-band signal to the frequency of X-band signal and calculate the difference of these two signal. Then, the extrapolation algorithm was used here to deduct the interference error of the earth ionosphere and the interplanetary plasma. Based on the above work, the electron column concentrations of lunar ionosphere was explored preliminary. The maximums of electron column concentrations are between $0.4 \times 10^{16}-0.5 \times 10^{16}$ $\mathrm{el} / \mathrm{m}^{2}$, are two times of the maximum result from Luna 19/22, are 1-2 orders higher than the SELENE result, but well-matched with the result from CPLEE. These results show that the lunar ionosphere is clearly exist and much stronger than we expected. The result here gives a positive support and some dynamical constrains for the scientific objective of the very low frequency radio astronomical payload onboard the Chang'E-4 lander mission. But it also raises a new question that the characteristics and formation mechanism of a stronger lunar ionosphere is remain unknown. More observations will be performed for further scientific targets.

lunar ionosphere, the service module of Chinese circumlunar return and reentry spacecraft, occultation, local correlation, electron column concentrations

doi: 10.1360/N972016-00386 